\title{
Analysis of selected properties of warming system prepared with various plastering mortar
}

\author{
Wioletta Godlewska ${ }^{1, *}$, and Artur Koper ${ }^{1}$ \\ ${ }^{1}$ Warsaw University of Technology, Faculty of Civil Engineering, Mechanics and Petrochemistry, \\ Łukasiewicza 17, 09-402 Płock, Poland
}

\begin{abstract}
Nowadays, one of the most important challenge in civil construction is design, build and use buildings in sustainable development way. This article describes one of the most important thermomodernization undertaking, which is increase of insulation of external walls. The research was prepared in special technology on samples with silicon, mineral, acrylic thin-layer plasters and with adhesive mass only. Purpose of the research was to analyze the physical and mechanical properties of the additional layer with this four variants of plastering mortar. The research, which was made by authors showed that the thin layer plasters are characterized by resistance to environmental factors, which they are directly exposed. The connection between the individual layers of the thermal insulation system secures durability of the plasters. The samples with mineral plastering mortar were characterized by the highest interlayer adhesion
\end{abstract}

\section{Introduction}

Environmental and human friendly construction implements the principles of sustainable development by saving natural resources of our glob. This concept should be understood among other things, as improving the energy efficiency of a building [1,2]. The term "thermo-modernization" refers to responsible undertakings, which helps reducing seasonal consumption of heating energy and power ordered in existing buildings. One of thermomodernization tasks is insulation of complete partitions such as external walls, roofs, ceilings above basement and the last living rooms tier, which are surfaces through a lot of heat from heated buildings is lost. It depends on adding to existing partitions new layers with high insulation properties. Thanks of this thermo-modernization undertaking we reduce the waste of heat and bills connected with heating [3-5]. Good knowledge about physical properties of the building materials give us possibility to design, then build and use the buildings in correct way.

Plastering mortars are finishing materials using to make both internal and external plasters. There are traditional and thin-layer plasters. The traditional plasters are cementlime ones, which should be applied by the layer with at least $15 \mathrm{~mm}$ of thickness. The layer of thin-layer plasters is 1-6 mm of thickness. This plastering mortar can be in the form

\footnotetext{
* Corresponding author: wioletta.godlewska@interia.eu
} 
of dry mixture or ready to use plaster mass. Depending on place and method of production the plastering mortar are divided into two kinds:

- plastering mortars produced in the factory - mortar, which ingredients were selected and mixed in the factory;

- plastering mortar prepared in construction site - mortar, which ingredients were selected and mixed in construction site [6-8].

Currently produced plastering mortars are mixtures of many ingredients, which should be appropriately selected, so the material has suitable properties. The research was conducted on the thin-layer plasters. The purpose of the research undertaken by the authors was to analyze the physical and mechanical properties of the additional layer with four variants of plastering mortar: mineral, acrylic, silicone and with adhesive mass only. All of the plastering mortar samples were prepared and carried out according to ZUAT 15/V 0.3/2003 [9] and ETAG number 004 [10].

The purpose of research was demonstrated a clear dependence between the physical and mechanical properties for four different variants of plastering mortar. Both - the type and the quality of the used materials are strictly connected with the durability of the warming system [11-13]. Right choice of plastering mortar has as a task to protect external walls against environmental factors like: temperature differences in summer and winter, rainfall and snowfall (periodicity dampness). They protect also against biological and mechanical factors. The resistance to this factors influence is fundamental way to service life of warming system. Resistance to weather conditions is also crucial for the sustainability of the thermal insulation system. High durability means no need for repairs and is more beneficial for the natural environment $[11,14,15]$.

In the research presents in the article KSU-SDB glue and the plastering mortar were subjected to the following tests:

- determination of the texture of the adhesive;

- frost-resistance of warming system;

- interlayer adhesion in a warming system;

- determining the loss on ignition;

- water absorption.

\section{Materials and methods}

\subsection{Materials}

All materials, used in the described research, were already prepared components, produced by Polish manufacturer. To test were used:

- polystyrene ESP variety 70;

- INGRIDIENT 1 - glue - dry mineral mixture based on hydraulic and polymeric binders

with admixture;

- reinforcing mesh;

- underlay of plaster:

- INGRIDIENT 2 - mixture of water dispersion modified with polymeric resin with fillers;

- INGRIDIENT 3 - mixture of water glass dispersion modified with polymeric resin, surfactants and rheological measures with fillers based on quartz calcium carbonate.

- INGRIDIENT 4 - mixture of water dispersion modified with polymeric resin.

- plastering mortar:

- INGRIDIENT 5 - ready to use plaster mass based on modified acrylic binder and fillers;

- INGRIDIENT 6 - ready to use plaster mass based on water glass, acrylic resin, surfactants with fillers; 
- INGRIDIENT 7 - dry mixture of mineral resins, mineral fillers and modifying admixtures.

All materials were delivered in a factory packaging's with a capacity of $25 \mathrm{~kg}$.

\subsubsection{Preparation of samples}

The samples were prepared in two stages in according to special technology, which uses mineral, silicone and acrylic plastering mortar or adhesive mass only. In the first stage reinforcing layer, which was made of INGRIDIENT 1 and reinforcing mesh, was prepared. The suitable mixture of glue and water was put on the polystyrene samples. Then reinforcing mesh was sunk in the samples. In the second step plastering mortar was made. Ready plaster mass was used to prepare samples with acrylic and silicone plastering mortar. The plaster mass was applied by steel plasterer's float. To prepare mineral plastering mortar - dry mineral resins, fillers and modifying admixtures were mixed with water. Next, the prepared mixture was put on the samples.

\subsection{Methods}

\subsubsection{Test of the texture of the adhesive}

The test relied on determining the cone's immersion (total mass $300 \pm 2 \mathrm{~g}$ ) in the mortar. The research was done three times, each time applying a new portion of the mortar. The measure of the consistency is the depth in centimeters, on which the cone was immersed.

\subsubsection{Test of the loss of ignition}

The test of determining the loss of ignition was prepared at definite temperatures: - for plastering and adhesive masses or grounding solutions $450 \pm 5^{\circ} \mathrm{C}$ and $950 \pm 5{ }^{\circ} \mathrm{C}$; - for plastering mortars $450 \pm 5^{\circ} \mathrm{C}$.

The cooling of the sampes was carried out in a desiccation.

\subsubsection{Test of the frost-resistance of warming system}

The frost-resistance test was performed on samples, which were used during the test of water absorption. The research was consisted of 25 cycles, which were participated on: - immersing the side with plaster down in the water at temperature $20 \pm 2{ }^{\circ} \mathrm{C}$ for 24 hours; - freezing the sampes at temperature $20 \pm 2^{\circ} \mathrm{C}$ for 24 hours.

The evaluation of forest-resistance was base on a visual checking condition of the plastering mortar.

\subsubsection{Test of the interlayer adhesion in a warming system}

The interlayer adhesion test was performed on $25 \times 25 \mathrm{~cm}$ samples, which were prepared in special technology on 28 days before the test. On the samples were cut places in the shape of a $5 \times 5 \mathrm{~cm}$ square. Then, $5 \times 5 \mathrm{~cm}$ steel tiles were glued in this places by epoxy resin. In the test minimum strength was analyzed, with which it was possible to separate the tiles from the samples. 


\subsubsection{Test of the water absorption}

The test of the water absorption was made on $25 \times 25 \mathrm{~cm}$ samples. The samples were prepared in according to special technology with silicone, mineral, acrylic plastering mortar and with adhesive mass only. For 21 days since plaster application, the samples were stored in laboratory at temperature $20 \pm 2{ }^{\circ} \mathrm{C}$ and $\mathrm{RH}=50 \pm 15 \%$. After this period of time they were sealed by one layer of epoxy resin (with $10 \%$ hardener content) on the side and on the top. After next 7 days, the samples were placed in the water at temperature $20 \pm 2{ }^{\circ} \mathrm{C}$ (the side with plaster down to a depth of 2-10 mm). The test was consisted of weighing the samples after 3 minutes, 1 hour and 24 hours since the immersing in water. It was carried on 6 samples with each 4 variants of plastering.

\section{Results}

\subsection{Results of the adhesive texture test}

Determination of the adhesive texture was prepared three times, each time using a new portion of the mortar. Research results are presented in Table 1.

Table 1. The results of determination of the adhesive texture.

\begin{tabular}{|c|c|c|}
\hline Number & $\begin{array}{c}\text { A depth of immersing cone } \\
\text { in the mortar }\end{array}$ & Requirements $Z U A T-15 / V$ \\
\hline 1 & 7.5 & \multirow{2}{*}{ \pm 1 cm in relative to value declared by } \\
mortar supplier
\end{tabular}

The depth of immersing declared by mortar supplier was $8 \mathrm{~cm}$, so the achieved results were in line with requirements.

\subsection{Results of the loss on ignition}

Table 2 presents results of the loss on ignition test. The received results according to ZUAT- $15 / \mathrm{V}$ should fit in $\pm 10 \%$ range in connection to value declared by mortar supplier, which is $2.55 \%$.

Table 2. The results of determination of the loss on ignition.

\begin{tabular}{|c|c|c|c|c|c|}
\hline Number & $\begin{array}{c}\text { Mass of } \\
\text { sample with } \\
\text { melting-pot } \\
\text { before } \\
\text { ignition [g] }\end{array}$ & $\begin{array}{c}\text { Mass of } \\
\text { sample with } \\
\text { melting - pot } \\
\text { after ignition [g] }\end{array}$ & $\begin{array}{c}\text { Mass of } \\
\text { melting } \\
\text { - pot[g] }\end{array}$ & $\begin{array}{c}\text { Loss by } \\
\text { ignition[\%] }\end{array}$ & $\begin{array}{c}\text { Requirements } \\
Z U A T-15 / V\end{array}$ \\
\hline 1 & 20.5 & 20.4 & 15.4 & 2.80 & \multirow{3}{*}{$\begin{array}{l} \pm 10 \% \text { range } \\
\text { in connection to } \\
\text { value declared by } \\
\text { mortar supplier }\end{array}$} \\
\hline 2 & 31.4 & 31.3 & 26.3 & 2.50 & \\
\hline $\begin{array}{c}\text { On } \\
\text { average }\end{array}$ & & & & 2.65 & \\
\hline
\end{tabular}




\subsection{Results of frost-resistance test}

From the point of view of resistance for external environmental influence, the most important property is frost-resistance. To conduct the experiment were needed 16 samples. Ten of them were prepared on 28 days before the test. Six of them were used earlier in water absorption test. A visual checking the condition of plastering mortar didn't show any changes. The results were in line with requirements included in ZUAT-15/V and ETAG number 004.

\subsection{Results of interlayer adhesion in a warming system}

To prepare the test of interlayer adhesion, to the samples were added silicone, mineral and acrylic plastering mortar. The samples were held in laboratory for 28 days before the test. For each plastering mortar eight trials were made to tear away tiles from the samples. In the Table 3 are presented average results of interlayer adhesion test.

Table 3. The results of interlayer adhesion test

\begin{tabular}{|c|c|c|c|c|}
\hline $\begin{array}{c}\text { Kind of plastering } \\
\text { mortar }\end{array}$ & $\begin{array}{c}\text { Average } \\
\text { tearing force }[\mathrm{N}]\end{array}$ & $\begin{array}{l}\text { Surface of } \\
\text { tiles }\left[\mathrm{mm}^{2}\right]\end{array}$ & $\begin{array}{r}\text { Average } \\
\text { interlayer } \\
\text { adhesion - } \\
\mathbf{R}_{\text {Śr }}[\mathrm{kPa}] \\
\end{array}$ & $\begin{array}{c}\text { Requirements } \\
\text { ZUAT-15/V }\end{array}$ \\
\hline Silicone plaster & 260 & 2450 & 106 & \multirow{3}{*}{$\mathrm{R}_{\mathrm{Sr}}>100 \mathrm{kPa}$} \\
\hline Acrylic plaster & 255 & 2450 & 104 & \\
\hline Mineral plaster & 246 & 2450 & 101 & \\
\hline
\end{tabular}

The Figure 1 presents comparison of the interlayer adhesion in three variants of plastering. The highest interlayer adhesion was characteristic for samples with mineral plastering mortar. The lowest results achieved the samples with silicone ones. Interlayer adhesion of mineral ones were accordingly by $2 \%$ and by $5 \%$ higher than acrylic and silicone ones.

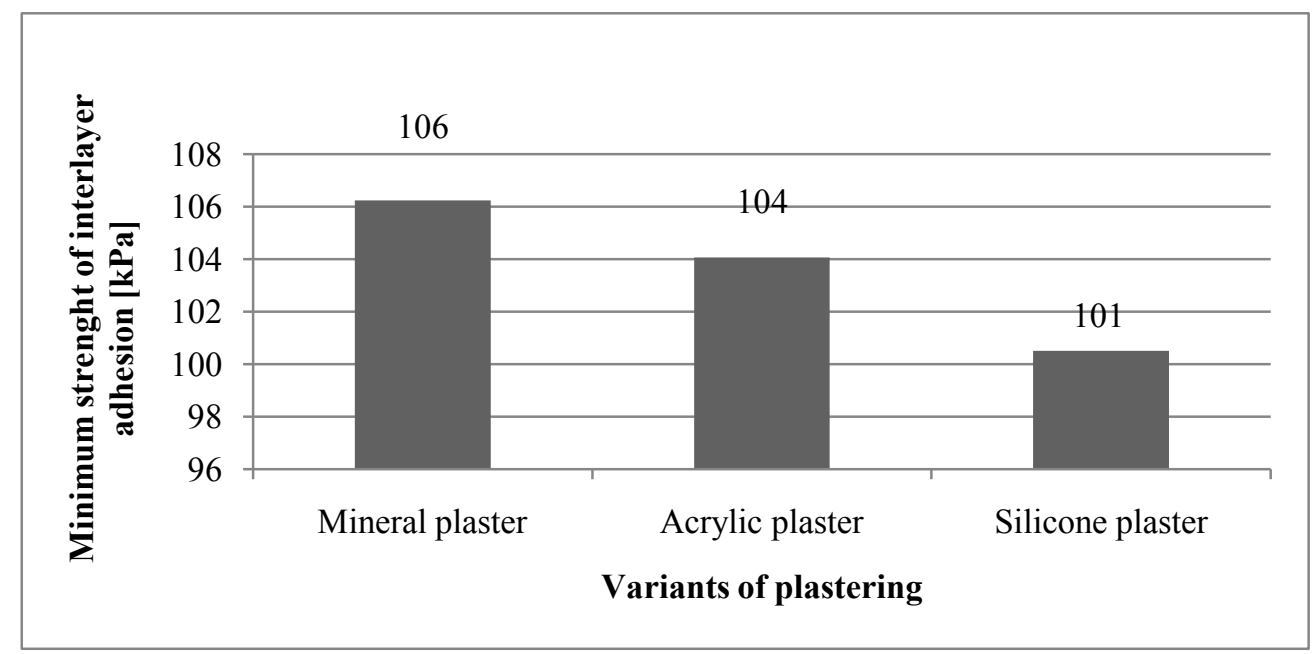

Fig. 1. Comparison of the interlayer adhesion 


\subsection{Results of water absorption test}

Research results are presented in Table 4 for each variant of plastering.

Table 4. Results for the water absorption test

\begin{tabular}{|c|c|c|c|c|c|c|c|}
\hline 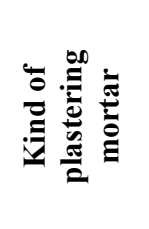 & 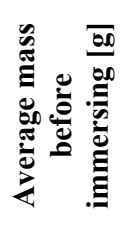 & 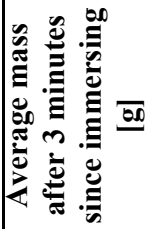 & 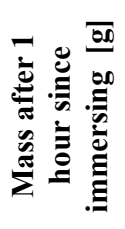 & 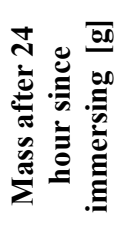 & 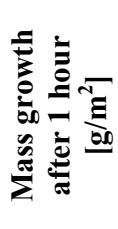 & 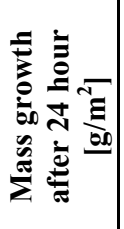 & 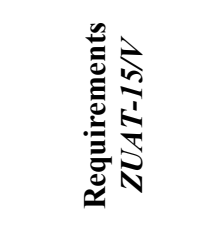 \\
\hline $\begin{array}{l}\text { Silicone } \\
\text { plaster }\end{array}$ & 400 & 406 & 441 & 443 & 131 & 634 & \multirow{4}{*}{$\begin{array}{c}\text { No more than } \\
1000 \mathrm{~g} / \mathrm{m}^{2} \\
\text { after } 1 \text { hour, } \\
\text { specific } \\
\text { numerical value } \\
\text { after } 24 \mathrm{~h} \\
\text { immersion }\end{array}$} \\
\hline $\begin{array}{l}\text { Acrylic } \\
\text { plaster }\end{array}$ & 427 & 437 & 443 & 467 & 104 & 514 & \\
\hline $\begin{array}{c}\text { Mineral } \\
\text { plaster }\end{array}$ & 466 & 490 & 511 & 527 & 362 & 643 & \\
\hline $\begin{array}{l}\text { Adhesive } \\
\text { mass only }\end{array}$ & 297 & 217 & 328 & 338 & 184 & 365 & \\
\hline
\end{tabular}

The mass growth is presented on Figure 2 and Figure 3. The samples with mineral plaster were marked with the highest water absorption after 1 hour of immersing $-362 \mathrm{~g} / \mathrm{m}^{2}$. Water absorption of mineral samples were about $248 \%$ higher than acrylic ones, about $176 \%$ than silicate ones and about $96 \%$ than samples with adhesive mass only.

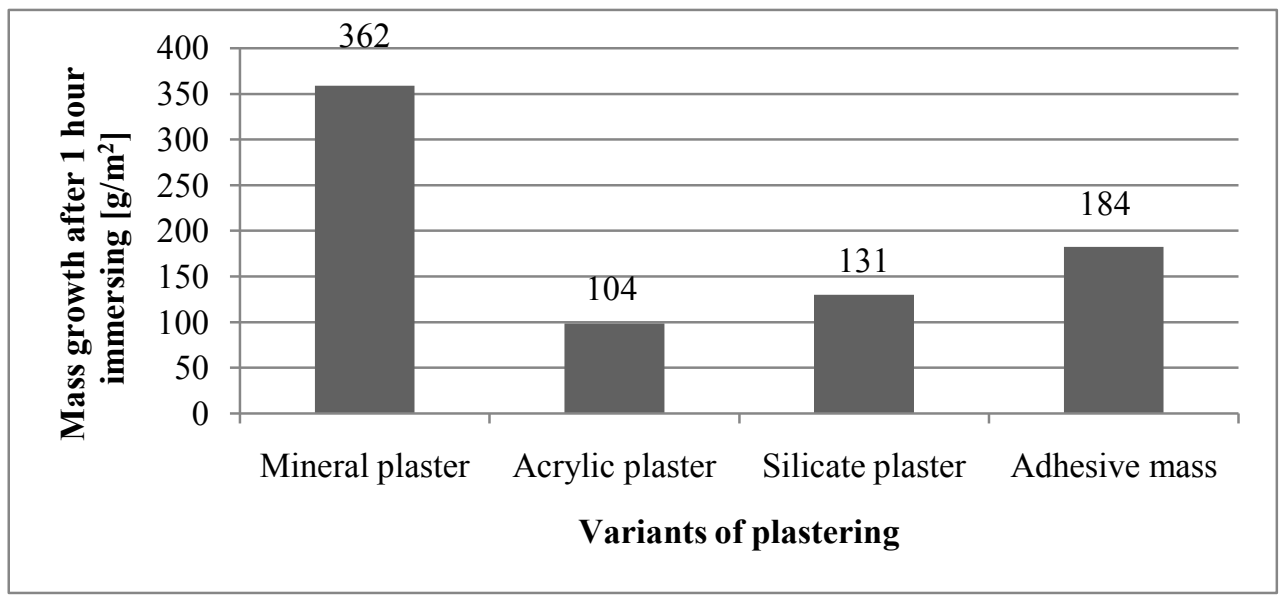

Fig. 2. Comparison between medium mass growth after 1 hour immersing in each variants. 


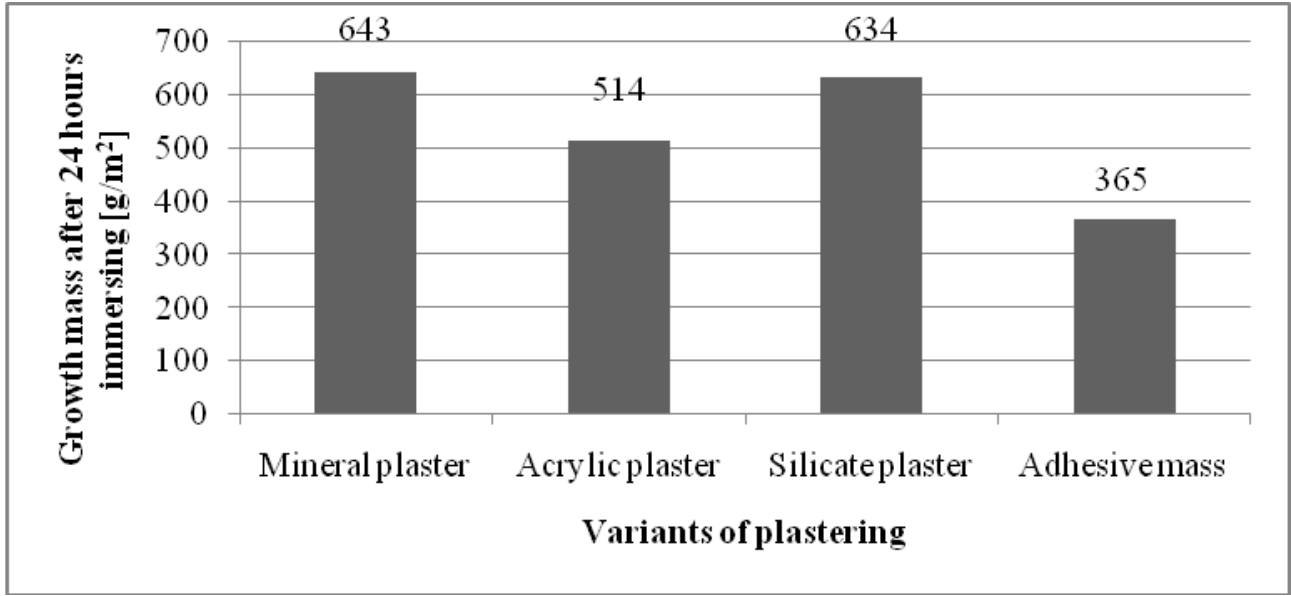

Fig. 3. Comparison between medium mass growth after 24 hours of immersing.

The mass growth after 24 hours from the start of immersing the samples in the water was speared a bit different than the results after 1 hour. The highest water absorption was observed for the samples with mineral plaster $-643 \mathrm{~g} / \mathrm{m}^{2}$. Water absorption of mineral samples were about $25 \%$ higher than acrylic ones and about $57 \%$ higher than samples with adhesive mass only. The samples with mineral and silicate plasters had almost the same mass growth.

The results of all research were in line with requirements included in ZUAT-15/V

\section{Conclusions}

The research results showed that the thin-layer plasters are characterized by resistance to environmental factors, which they directly exposed. The results of the loss of ignition and water absorption and frost-resistance were in line with requirements included in ZUAT15/V0.3/2003 and ETAG number 004.

In water absorption test mineral plasters was marked by the highest results after 1 hour of immersing. The samples achieved almost 3.5 times higher water absorption than acrylic plasters, almost 2.8 times higher than silicon ones. The reason of the achieved results can be the method of preparing. To prepare mineral plastering mortar - dry mineral resins, fillers and modifying admixtures were mixed with water. The silicon and acrylic ones were ready to use plaster mass.

The connection between the individual layers of the thermal insulation system secures durability of the plasters. The samples with mineral plastering mortar were characterized by the highest interlayer adhesion.

The physical properties of external partitions are changing regarding to kind of used mortar plaster. It is important to choose material building in well - balanced way to achieve the best parameters of warming system, which help us to limit waste of heat in buildings. Authors recommended to select acrylic plasters, which due to the lowest water absorption secures suitable long service life of warming system without repairing them.

\section{References}

1. A. Chel and G. Kaushik, Alexandria Eng. J. (Faculty of Engineering, Alexandria University, 2013), In Press

2. S. A. Alkaff, S. C. Sim, M. N. Ervina Efzan, Renew. Sustain. Energy Rev. 60, 692-713 
(Elsevier, 2016)

3. A. Wȩglarz, P. G. Gilewski, Procedia Eng. 153, 862-865 (2016)

4. F. F. Cyrille Vincelas, T. Ghislain, J. Build. Eng. 9, August 2016, 155-163 (Elsevier Ltd, 2017)

5. A. Dombayci, Ö. Atalay, Ş. Güven Acar, E. Yilmaz Ulu, H. Kemal Ozturk, Sustain. Energy Technol. Assessments 22, 1-8 (2017)

6. J. Bochen, Problemy trwałości tynków zewnętrznych $w$ warunkach oddziatywań środowiskowych (Wydawnictwo Politechniki Śląskiej, Gliwice, 2015)

7. G. E. and C. W., Materiały budowlane, ćwiczenia laboratoryjne (Oficyna Wydawnicza Politechniki Warszawskiej, Warszwa, 2013)

8. Skalmowski W., Technologia materiałów budowlanych, T. II (Warszawa, 1966)

9. Zalecenia udzielania aprobat technicznych ITB ZUAT-15/V.03/2003, Zestaw wyrobów do wykonania wyrobów ociepleń z zastosowaniem styropianu termoizolacyjnego $i$ pocienionej wyprawy elewacyjnej (Warszawa, 2013)

10. Wytyczne do Europejskich Aprobat Technicznych ETAG nr 004, Złożone systemy izalacji cieplnej $z$ wyprawkami tynkarskim (Warszawa, 2000)

11. J. Bochen, Archit. Civ. Eng. Environ. 6, 1, 17-26 (2013)

12. T. Cerulli, C. Pistolesi, C. Maltese, D. Salvioni, Cem. Concr. Res. 33, 9, 1375-1383 (2003)

13. P. Hradil, T. Toratti, E. Vesikari, M. Ferreira, T. Häkkinen, Constr. Build. Mater. 53, 162-172 (Elsevier Ltd, 2014)

14. J. Souza, A. Silva, J. de Brito, E. Bauer, Eng. Fail. Anal. 83, October 2017, 141-155 (Elsevier, 2018)

15. Y. S. Vytchikov, I. G. Belyakov, M. E. Saparev, in Procedia Eng. 153, 856-861, (2016) 